\title{
Pozoruhodná publikace o střední Evropě
}

\author{
Agnieszka Janiec-Nyitrai (Budapešt)
}

Róbert Kiss Szemán - Andor Mészáros (eds.): Středoevropské kulturní formace v boji proti komunistické totalitě. Esztergom: Nadace svatého Vojtěcha pro výzkum střední a východní Evropy, 2017. 188 s. ISBN 978-963-89709-1-6

Publikace Středoevropské kulturni formace v boji proti komunistické totalitě, jejímiž editory jsou budapeštští slavisté Róbert Kiss Szemán a Andor Mészáros, představuje pozoruhodný pokus o zmapování méně známé oblasti výzkumu středoevropských kulturních, historických a v neposlední radě také politických vztahů. Je sestavena ze třinácti studií z pera předních mad’arských, českých a slovenských vědců. Jednotlivé studie byly seřazeny do tři komplementárních částí a autoři jednotlivých příspěvků se soustředili na nejdůležitější formy resistence proti totalitnímu režimu především v Československu a v Mad’arsku. Publikace vznikla za finanční podpory Pamětního výboru 60. výročí revoluce a boje za svobodu 1956, a je to v pořadí další publikace věnovaná stř̌edoevropské problematice, jejímž nakladatelem je „Nadace svatého Vojtěcha pro výzkum střední a východní Evropy“. Zde je třeba zmínit dvě knihy, které díky tomuto nakladatelství spatřily světlo světa: A mai Csehország (Esztergom, 2013) od Andora Mészárose, a A mai Szlovénia (Esztergom, 2011) od Andora Mészárose, Ivana Halásze a Miklóse Somaiho, které rovněž pojednávají o středoevropské tematice.

První část publikace přinášející tři studie se zaměřuje na jevy obecnější. První ze studií, s názvem Problém hodnotových kritérii při dnešnich návratech $k$ literatuř a společnosti za oněch časư, jejímž autorem je český literární historik Pavel Janoušek, se soustředí na reflexi komunistické a nacistické totality z dnešní perspektivy a upozorňuje na rozpory mezi kritérii a hodnotovými postuláty v minulosti a v současnosti. Tento rozpor je obzvlášṫ znatelný při četbě textů $\mathrm{z}$ „oněch časů“, které jsou hodnoceny z dnešních hledi- sek a s použitím dnešních měřítek - takto vznikají mnohá nedorozumění, protože současný čtenář si neuvědomuje, jak fungovaly mechanismy moci. Autor analyzuje, jakým způsobem dochází $\mathrm{k}$ dezinterpretaci a $\mathrm{k}$ nepochopení totalitního režimu, který je pro mladé lidi něčím zcela cizím. Na příkladech jednotlivých jevů, např. jiného chápání svobody slova, Janoušek upozorňuje na nejdůležitější posuny v chápání minulosti z perspektivy dneška. Studie přináší velmi aktuální postřehy a zároveň reflektuje stav české společnosti a její vztah k minulosti. Autor zdůrazňuje, jak důležitý je objektivní, nezaujatý vztah k tomu, co bylo. Podle jeho soudu by se na tvarování společenských postojů měli podílet především historikové kultury a literární vědci, kteří dokáží upozornit na nový, jiný pohled na minulost. V ignoranci a nezájmu o minulost Pavel Janoušek spatřuje jisté nebezpečí a celou studii uzavírá znepokojující poznámkou: „A proto se také obávám, že by moji studenti za pár let mohli oněm časům porozumět o mnoho lépe než dnes - a možná až př́liš“ (s. 22).

Druhá studie s názvem Krádež jazyka - jazyk a totalitarismus, jejíž autorkou je Magdolna Balogh, která vydala $\mathrm{v}$ tomto roce $\mathrm{v}$ mad’arštině knihu Rabult ejtett értelmek: Irások közép-európai témákról (Budapest, 2017), věnovanou právě otázkám kulturního života $\mathrm{v}$ období totality ve střední Evropě, se dotýká velmi podstatné otázky, na niž naráží všichni badatelé věnující se otázkám totalitních systému - analyzuje mechanismy deformace a zneužití jazyka ve prospěch manipulace s lidmi - čtenáŕi, diváky nebo posluchači. Badatelka přibližuje, jak velkou křivdu spáchala manipulace s jazykem: „Krádeži jazyka berou člověku jeho vlastni identitu, aby se z něho 
stalo poslušné kolečko mocenského aparátu“ (s. 24). Autorka definuje, čím byl „totalitní jazyk“ a na konkrétních příkladech poukazuje na jeho výskyt v literatuře, přičemž si je vědoma toho, že se pohybuje na pomezí sociální psychologie, politologie a sociolingvistiky. Věnuje se také otázkám jazykové dimenze mocenské manipulace a monopolu totalitního jazyka na interpretaci jevů skutečnosti. Pozoruhodným způsobem rovněž akcentuje vznik svérázného modelu světa, který je vytvořen pod vlivem totalitního jazyka. Uvádí př́klady děl středoevropských autorů, kteří podlehli kouzlu totalitního jazyka, jako např. básně Wiktora Woroszylského nebo Ivana Skály.

Poslední studii tohoto bloku tvoří text Róberta Kiss Szemána Katolické literatury ve středni Evropě - traumata a kánony, jež pojednává o problémech se začleněním katolické literatury do národního kánonu. Badatel přibližuje negativní a opovržlivé chápání katolické literatury v období moderny, což vedlo k nucené marginalizaci katolické literatury a kultury vůbec. Postmoderní období přispělo $\mathrm{k}$ dalším negativním změnám: „Postmoderna mimo jiné rozkolísala př́značnou moderni dichotomii (asymetrické dvojice konzervativni - moderni atd.) Timto rozkolisánim ovšem zpochybnila i dosavadni diskurz o katolické literature a kultuře, ba i jejich právo na existenci“ (s. 47). Podle Szemána zde dochází k vrstvení traumat, což vede $\mathrm{k}$ pojmovému chaosu a $\mathrm{k}$ mnoha nedorozuměním. Badatel v tom však spatřuje jistou naději, protože právě postmoderna poskytuje možnost nalézt, anebo vytvořit nový myšlenkový rámec, v němž bude katolická kultura a literatura znovu fungovat. Další možnosti podle Kiss Szemána poskytuje také dekolonizační obrat. Za obzvlášt př́nosné lze označit odstavce věnované katolické kultuře z pohledu postkoloniální kritiky. Autor analyzuje rovněž periferizaci a podřazenost katolické kultury ve středoevropských národních kánonech, píše o její roztř́šštěnosti, z níž vyplývá mj. také její slabost. Pozoruhodné je, že autor rozebírá jisté náznaky restrukturizace kánonu, což může vést $\mathrm{k}$ tomu, že katolická literatura má šanci přece jen proniknout do národního kánonu jednot- livých středoevropských literatur. Zde je třeba zdůraznit, že Róbert Kiss Szemán se otázkou katolické literatury věnuje už dlouhodobě. Stačí zde zmínit studie Európske zázemie a niektoré charakteristické znaky stredoeurópskeho konzervativizmu a katolíckej literatúry 19. a 20. storočia (In: J. Dudášová (ed.): Slavistika v premenách času (štúdie z jazykovednej a literárnovednej komparatistiky), Prešov 2009, s. 327-334), Katolícke interkulturačné experimenty $v$ európskom umeni 19. a 20. storočia (In: E. Príhodová (ed.): Kontexty a inšpirácie katolíckej moderny. Ružomberok, 2011, s. 154-170), nebo nedávnou vydanou monografii „S oporou i bez opory...” Středoevropské tváre katolické literatury (Praha, 2017). Róbert Kiss Szemán spolu se Simonou Kolmanovou jsou také editory v češtině vydané antologie mad’arské katolické literatury Němá nauka stromi o spáse (Praha, 2014).

Další blok textů otevírá prríspěvek Edity Príhodové z Katolické univerzity v Ružomberoku. Její text Obraz nastupujúcej komunistickej totality $v$ tvorbe autorov katolickej moderny nastoluje otázku konkrétní realizace protikatolického utlačování slovenských autorů v letech 1945-1948. Přibližuje situaci katolických uměleckých časopisů, soustředí se na básnictví protikomunistického odporu a také popisuje osudy a básnickou tvorbu slovenských katolických básníků tvořících v emigraci (podrobněji zde analyzuje tvorbu Rudolfa Dilonga). Další část její studie je věnována katolickým básníkům tvořícím v Československu (navrhuje zde pozoruhodný rozbor dvou básnických sbírek Janka Silana). Z autorčiných analýz vyplývá, že slovenští katolicky zaměření autoři ve své tvorbě upozorňovali na možné nebezpečí komunismu a citlivým způsobem reagovali na rychle se měnící politickou a kulturní situaci.

Druhý text, který editoři zařadili do tohoto bloku, nese název Druhý život represe coby nová zakládajici událost českého katolicismu aneb Vznik obrazu spisovatele mučednika a napsal jej významný český badatel v oblasti katolické literatury Martin C. Putna (který je mj. autorem průkopnických publikací Česká katolická literatura 1848-1918 (Praha 1998) a Česká katolická literatura 1918-1945 (Praha, 2010). Autor si po- 
ložil za cíl odpovědět na otázku, co znamenal teror komunistické totality pro vývoj katolického smyšlení v českém kontextu a také jaký vliv na sebehodnocení katolických autorů měly komunistické represe. Putna upozorňuje na vznik pozoruhodného diskurzu spojeného s mučednictvím katolických umělců v Československu po převzetí moci komunisty a popisuje trpké zkušenosti vězněných autorů-katolíků. Zamýšlí se nad žánrovou reprezentací jednotlivých textů a všímá si, že zde absentuje klasicky chápaná próza, namísto ní jsou bohatě reprezentovány žánry nebeletristické jako memoáry a rozhovory. Putna vykresluje panoráma české katolické tvorby a vedle známých autorů jako Jan Zahradníček nebo Jaroslav Durych zmiňuje také méně známé spisovatele. Polemizuje s tvrzením, že katolická literatura v Československu 50. let byla zcela rozprášena a umlčena.

Různé formy odporu vůči komunistické totalitě zkoumá Pavel Matejovič v článku Niektoré z podôb kultúrnej rezistencie v obdobi rokov 1948 -1989 na Slovensku. Mapuje politicko-kulturní situaci v Československu a přibližuje také širší středoevropský kontext, např. reakci na mad’arské události z roku 1956, a také změny v slovenské literatuře, které lze zaznamenat od druhé poloviny padesátých let. Popisuje jednotlivé kulturní iniciativy, které vedly k postupnému uvolňování poměrů, což vedlo $\mathrm{k}$ vymezení se dvou pozoruhodných linií v polovině šedesátých let - obrodný kulturní proces (pražské jaro) a také vývoj alternativní kultury (která však nerezonovala do značné míry s politickou situací). Matejovič sleduje výrazné změny, které slovenské literatuře přinesla normalizace a rovněž se zmiňuje o slovenské exilové tvorbě. Zdůrazňuje potřebu terminologické přesnosti a vymezuje se vůči běžnému pojmu antikomunistický odpor, protože se mu toto označení zdá př́liš vágní. Nejpodstatnější rozdíl mezi literaturou před rokem 1989 a po roce 1989 badatel spatřuje v tom, že svobodná literatura není prostředkem, nemá něčemu sloužit, ale může být svobodným vyjádřením uměleckých postojů.

Následující studie ,Němá totalita v mad'arské próze druhé poloviny 20. století na příkladu ro- mánu Miklóse Mészölye Šavel (Saulus) zkoumá problematiku ticha a mlčení jako součásti antitotalitního literárního diskurzu. Autorka Simona Kolmanová analyzuje skryté zobrazení totality, na příkladu hrdinů románu ukazuje, jakými způsoby může člověk vzdorovat manipulačním technikám, jak může bránit svou identitu a jaké formy může mít neagresivní odpor vůči mechanismům totalitního systému. Lidská důstojnost a osobní svoboda, které jsou vystaveny manipulacím a lžím ničivé komunistické moci, mohou být bráněny právě pomocí distancování se a hledání odstupu od okolního světa. Kolmanová nabízí také pozoruhodnou typologii „němé“ totality v literatuře. Navrhuje rozdělení do tří hlavních významových oblastí: 1) u prvního typu literárních děl absentuje explicitní zobrazení totality, dominuje zde skryté vyjádření, což bylo samozřejmě dáno cenzurou; 2) díla druhého typu tematizují fenomén ticha a mlčení a je to právě případ Kolomanovou analyzovaného románu „Šavel“; 3) díla třetího typu zobrazují deformovaný jazyk komunikace - ,jazyk mluvčího je posluchači cizi, neznámý, nebo mu obsah výpovědi zůstává z nĕjakých jiných di̊vodů utajen“ (s. 108). Ve studii je podrobně rozebraná problematika ticha, mlčení a ne-komunikace a autorka ukazuje jejich zásadní roli v demaskování skrytých mechanismů totalitního systému.

V dalším příspěvku s názvem Obraz totality $v$ postkoloniálnej próze Tibor Žilka s použitím postkoloniálního diskurzu navrhuje rozdělení středoevropské prozaické tvorby druhé poloviny 20. století do několika skupin: 1) umělecko-politická próza; 2) dokumentárně-životopisná próza; 3) esejisticko-životopisná próza; 4) rodinná próza; 5) próza s námětem GULAGU; 6) vzpomínková próza. Na základě tohoto tř́i dění je na konkrétních př́ikladech ukázána charakteristika jednotlivých skupin. Žilka demonstruje, jakými způsoby se lze distancovat od tíživého nátlaku komunistické moci, jakými způsoby autoři popisují své zkušenosti a pokusy o zachování identity, lidské důstojnosti a svobody.

Ján Gallik ve studii Antitotalitná tvorba Jozefa Tótha na příkladu konkrétního autora poukazuje 
na to, jak vypadal život a tvorba autorů, kteří s komunistickým systémem nesouhlasili a nepodřídili se požadavkům ideologické tvorby. Jozefa Tótha, katolického kněze, básníka a prozaika, lze podle Gallika přiřadit ke klíčovým postavám slovenského křestanského disentu. Ve studii najdeme analýzu vybraných básní Jozefa Tótha. Gallik také přibližuje hlavní problematiku Tóthovy tvorby a její místo v slovenské básnické produkci padesátých až sedmdesátých let 20. století.

Studie uzavírající druhý tematický blok publikace nese název Rok 1956 v Mad'arsku ve středoevropských literárnich ohlasech (nástin) a jejím autorem je známý mad’arský literární vědec Csaba Gy. Kiss. Hlavní otázka, kterou si badatel položil, zní: „Jakým zpưsobem se v našem regionu utvárel obraz mad’arského šestapadesátého roku?“ (s. 148). Reakce jednotlivých reprezentantů středoevropského regionu jsou rozděleny do několika skupin: „svědectvi“, čili písemné projevy autorů, kteří byli očitými svědky mad’arských událostí roku 1956 (Adam Ważyk, Dobrica Ćosić, Hanna Adamiecka, Wiktor Woroszylski ad.) a díla, vzniklá v emigraci, která odrážejí události mad’arské revoluce. Dále pak Csaba Gy. Kiss nastiňuje, jak se ve středoevropské kulturní paměti formoval obraz mad’arské revoluce. Zvláštní pozornost je věnována polským autorům, kteří ve své tvorbě zobrazili tragické události 1956 roku (Zbigniew Herbert, Wisława Szymborska, Czesław Miłosz, Julian Przyboś a další).

Třetí tematický blok otevírá esej Totalitarismus proti lidskému světu - lidský svět proti totalitarismu. Neboli je možné čist antitotalitarismus z filozofické perspektivy, jejímž autorem je Attila Pató. Totalitarismus je zde analyzován z filozofického hlediska, autor zkoumá, co se děje s lidskou pamětí, soudností a vůlí pod vlivem ničivých totalitních podmínek. Člověk žijící v komunistickém režimu ztrácel právo na svobodu jednání, na individuální pamět, stával se izolovaným jednotlivcem a všechny mezilidské vztahy podléhaly deformaci.

V dalším příspěvku Revoluce proti sobě samým István Vörös uvažuje o roku 1968 v československém kontextu a zdůrazňuje jeho klíčovou roli pro pochopení klikatých cest střední Evropy ke svobodě. Badatel přichází se zajímavou tezí: „Český osmašedesátý je vzpourou vyzrálých procitlých intelektuáli proti hřichům vlastního mládi" (s. 168). Jako příklad uvádí Kunderův román Život je jin$d e, \mathrm{v}$ němž spisovatel účtuje $\mathrm{s}$ vlastní minulostí a s minulostí celé své generace, která se nechala svést atraktivními komunistickými hesly a sliby. Vörös podrobně analyzuje vystoupení českých spisovatelů na sjezdu Svazu československých spisovatelů v roce 1967, píše o tom, že myšlenkové rozpětí sjezdu zasahuje minimálně sto let do minulosti a nejméně deset let do budoucnosti. Vrací se k projevům Milana Kundery, Ivana Klímy, Jana Skácela a přichází s pozoruhodnou myšlenkou, že v podstatě vše, co se odehrálo v Československu v roce 1968, proběhlo již dříve na sjezdu Svazu československých spisovatelů.

Celý blok a také celou publikaci uzavírá studie Lubomíra Machaly Manipulace jako univerzálni nástroj totalit různého charakteru. Autor zkoumá otázky manipulace a spolu s Milanem Kunderou, Petrem Ulrychem, Ladislavem Šerým a dalšími spisovateli demaskuje ničivé působení a manipulační vliv imagologické moci. Zaměřuje se na novější českou tvorbu, nicméně konstatuje, že metody „totality spotřeby“ jsou velmi podobné metodám, které využívají všechny totalitní systémy.

Publikace Stredoevropské kulturni formace $v$ boji proti komunistické totalitě si určitě zaslouží pozornost a je zajímavým pokusem o celkový a zevrubný pohled na období, jemuž se teprve v posledních letech dostalo náležité pozornosti. Studie shromážděné $\mathrm{v}$ publikaci přinášejí nové poznatky a informace a nabízejí nové perspektivy výzkumu středoevropského regionu. Každý z autorů nabízí nový pohled na zkoumanou tematiku, která se v dnešní době stává obzvlášt aktuální. Je sice škoda, že se nepodařilo zmapovat podrobněji také polský kontext (i když se hojně objevuje např. v příspěvku Csaby Gy. Kisse nebo Magdolny Balogh), a především pozvat také polské historiky a literární vědce. Nicméně i přesto vznikla publikace, která je po všech stránkách přínosná a otevírá nové cesty výzkumu středoevropské kultury v kontextu národních a litera- 
tur. Důležité je, že iniciativa vytvořit zevrubný ze strany mad’arských slavistů a badatelů střední pohled na středoevropské literatury vyšla právě Evropy.

PhDr. Agnieszka Janiec-Nyitrai, PhD.

Ústav slovanské a baltské filologie

Univerzita L. Eötvöse

Múzeum krt. 4/D., 1088 Budapešt', Mad'arsko

janiec.nyitrai@gmail.com 